Marquette University

e-Publications@Marquette

$1-1-2008$

\title{
Artisans, Athletes, Entrepreneurs, and Other Skilled Exemplars of the Way
}

Alex Stewart

Marquette University, alex.stewart@marquette.edu

Felissa Lee

Marquette University, felissa.lee@marquette.edu

Gregory N.P. Konz, S.J.

Regis University

Accepted version. Journal of Management, Spirituality \& Religion, Vol. 5, No. 1 (2008): 29-55. DOI. (C) 2008 Taylor \& Francis (Routledge). Used with permission. 
Artisans, Athletes, Entrepreneurs, and other Skilled Exemplars of the Way [1]

\author{
Alex Stewart \\ Department of Management \\ Marquette University \\ Milwaukee, WI 53201-1881 \\ Phone (414) 288-7188 \\ Fax (414) 288-1965 \\ Alex.Stewart@Marquette.edu
}

Felissa K. Lee

Department of Management

Marquette University

Milwaukee, WI 53201-188

Phone: (414) 288-3905

Felissa.Lee@Marquette.edu

Gregory N. P. Konz, S. J.

Regis University

Denver, CO 80221-1099

Phone (303) 964-5797

gkonz@ regis.edu 
Artisans, Athletes, Entrepreneurs, and Other Skilled Exemplars of the Way

\begin{abstract}
We introduce management and spirituality scholars to the "knack" passages from the c. 4th century B.C.E. text, the Zhuangzi 莊子. The knack passages are parables about low status figures, such as wheelwrights, furniture makers and cooks, whose actions offer insights into the spirituality of ordinary work and, we argue, of entrepreneurship. Such non-corporate settings are lesser-studied domains for spirituality. Ancient Chinese writings have been noticed by spirituality and management writers but we call for deeper scholarly textual attention. We seek also to model more attention to the renaissance in scholarship on classical China. More ambitiously, we hope to show that these passages are not only germane but worthy of careful consideration. Our efforts reflect the influence of Slingerland's (2003) study of "effortless action" as a central soteriological goal in ancient China.
\end{abstract} Keywords. Alertness, Chinese philosophy, Daoism, Entrepreneurship, Spirituality, Zhuangzi

\title{
The Zhuangzi.
}

The Zhuangzi ([Chuang Tzu] 莊子, c. $4^{\text {th }}-2^{\text {nd }}$ B.C.E.) has had a pervasive impact in Chinese culture and been lauded as a master work of world literature (Ivanhoe, 1993; Mair, 2000; Miller, 2003, p. 31). Along with the Mengzi (孟子, "Mencius"), it is one of the earliest writings to bear the imprint of one literary stylist, who was either a man named Zhuangzi (fl. c. 320 B.C.E.) or one of his disciples (hence, "Zhuangzi" refers to the writer and "the Zhuangzi" refers to the text). In this era, clear distinctions did not separate "philosophical" from "religious" discourse, nor the "Daoist" tradition (the Zhuangzi) from the "Confucian" (the Mengzi) (Brook, 1993; Cook, 1997; for dating Chan, 2000 and Graham, 1981; 1990; compare Slingerland, 2003, pp. 282, 285-286; Roth, 1993). The text is also typical of its time in bearing the marks of multiple authors, traditions, and time periods (likely $4^{\text {th }}$ to $2^{\text {nd }} \mathrm{c}$. B.C.E.). However, the passages we draw upon are generally regarded as being written by either Zhuangzi or by writers of the "Zhuangzi school" (Coutinho, 2004, pp. 35-37; Lin, 2003; Mair, 2000; Roth, 1993; 2003a, Chap. 2; for the intellectual context see Coutinho, 2004, Chaps. 2, 5 and Hansen, 1992, Chaps. 2-4; 2003).

The "knack" passages. These passages, first categorized and labeled by Needham (1956, pp. 121-127), are relatively accessible and moreover crucial if we wish to "come to a fuller... appreciation of the Dao" as understood in the Zhuangzi (Ivanhoe, 1993, p. 640). "Zhuangzi believes one cannot directly say what the Dao is but... one can talk about examples of sages acting in accordance with it [and in particular those] individuals [who] all exhibit some form of skillful activity" (as above). In so acting these individuals "best 
exemplify [Zhuangzi's approach to reaching] the ultimate spiritual state" (Carr and Ivanhoe, 2000, p. 73). For a list of these and closely related passages, and the page references to the leading scholarly translations and the most recent Chinese concordance, please see Table One. The "balm" (or trader) passage is not included by either Needham or Graham (Roth, 2003, p. 162), but we agree with Ivanhoe (1993) and include it.

\section{PLEASE INSERT TABLE 1 ABOUT HERE}

\section{Overview of the Paper}

We begin by placing our discussion in several contexts. First we address the relevance of these passages for current thinking on spirituality and business. We outline the sinological context of the texts, the difficulties of comprehending such ancient texts, and the approach we have taken to respond to these difficulties. Next, the heart of our paper is a detailed consideration of the meaning of these passages. We conclude by noting some of the challenges of learning from other spiritual traditions. By this point we hope to have made three contributions. First, we offer the first overview of all the knack passages. The literature to date has focused on one or two at a time.

Second, we make a modest contribution to that literature with our discussion of "the paradox of (non)

instrumentality", whereas scholarly controversy to date has focused on the paradox of wu-wei (discussed below). Finally, we offer an unusually in-depth scholarly approach to a spiritual text and a context that is not well represented in the management and spirituality literature.

\section{Spirituality and Business}

Interest in spirituality, philosophical traditions or religion and business has grown rapidly in the years following the 1999 publication of Mitroff and Denton's A Spiritual Audit of Corporate America (Pauchant, 2002). It has become the subject of increasing academic research (Heaton, Schmidt-Wilke and Travis, 2004). The business press also displays increased interest in the intersection of spirituality and business in traditional firms (Kinjerski and Skryanek, 2004) and entrepreneurial enterprises (Bulger, 2002). Interest in pedagogical issues that arise when teachers bring spirituality into the business classroom has grown in tandem with the interest of researchers and practitioners (Bell and Taylor, 2004).

Many definitions of "spirituality" exist for use in delineating the field of spirituality and business (Krishnakumar and Neck, 2002). Defining "spirituality" in a way that accommodates both Western scholarly practice and the Zhuangzi is difficult. Moreover, the sinology literature appears rather uninterested in this definitional issue, despite its attention to topics such as the "highest spiritual state" (Slingerland2003). A broad 
definition that serves our purpose sees "spirituality" as the process of experiencing real meaning in work that goes beyond material rewards. This experience of real meaning comes from the sense of harmony that comes from selffulfilling work, work that helps us reach our full potential and live out our deepest values (Harrington, Preziosi and Gooden, 2001; Lips-Wiersma, 2002). This definition addresses many themes in the Zhuangzi, with the proviso that self-fulfillment in that text refers to a "tenuous", not superficial self. More strongly, Zhuangzi argued against a selfcentered practice. Spirituality in the Zhuangzi can also be seen to resonate with Mitroff's (2003, p. 377) finding that spirituality at work refers to "the feeling of being totally connected with everything else in the universe." (Compare the bell stand maker Qing, below.) However, even here the "connection" sought in the Zhuangzi - if that is quite the word - is very specific to a time and place, whereas Mitroff's expression suggests a fuzziness not found in Zhuangzi's writing. These are examples of the challenges of using language from current Western understandings to parse the ancient Chinese text.

Although we will propose only a provisional solution to the question, "what does spirituality" mean in the Zhuangzi, we do seek to enrich the current literature in spirituality and business in two ways. The first is to examine the role of spirituality in everyday work and in entrepreneurship. As noted earlier, the role of spirituality in entrepreneurship is topical in the business press but finds little attention in academic research (Konz and Jackson, 2002). For example, only three of 32 papers in the Handbook of Workplace Spirituality and Organizational Performance (Giacalone and Jurkiewicz, 2003) include any reference to entrepreneurship, and the references that are made are either incidental or metaphorical. Not surprisingly, the Handbook pays even less attention to the work of carpenters and other crafts people. Research on the development of entrepreneurs suggests that the desire for self-fulfillment is a principal motivation for people who decide to found their own businesses (Carter, Gartner and Shaver, 2004; Katz, 1994). An unanswered question, then, is "How do artisans and entrepreneurs find meaning in their work?"

The second way this study contributes to spirituality and business is by introducing a formative text in the Chinese tradition as relevant for exploring this question. This also is new territory for work on organizational spirituality; the Handbook (Giacalone and Jurkiewicz, 2003) has no references to Daoism. The earlier collection edited by Biberman and Whitty (2000) implies a generalized interest in the topic but offers little development of the knowledge base (pp. 38, 152, 289, 338-339, 345-346). We hope to demonstrate that this generalized interest was well founded and that humanistic study, such as textual study of the Zhuangzi, helps to heal "the rift between the 
discourse of spirituality and the discourse of organizational science” (Benefiel, 2003, p. 372). It also gives us a method for capturing the richness of human motivation that lies outside of the traditional qualitative and quantitative methods for studying human behavior (Benefiel, 2003; Fornaciari and Lund Dean, 2001).

\section{Challenges in Understanding the Zhuangzi}

The Zhuangzi is notoriously hard to interpret due to its unique uses of language and "literary playfulness and satiricalness" (Mair, 2000, p. 31; also Graham, 1981, pp. 27-33; Lin, 2003; Paper, 1995). These difficulties compound the challenge of interpreting texts that reflect the worldviews of over two millennia ago (Bokenkamp: 1997, pp. xiv-xv; Coutinho, 2004, Chap. 3; Hansen, 1992, Chap. 1). The Zhuangzi was written in "late Old Chinese" (Fuller, 1999, pp. 16-17). Current Mandarin is five major linguistic transformations removed. Our only hope for resolving this challenge is a careful reading. Here we agree with Phan's (2003) prescription that, if we wish to incorporate different religious traditions, we need to pay them deep scholarly attention. Fortunately, the Zhuangzi has received substantial scholarly attention and benefited from an "efflorescence" of research on older Chinese writings (reflected, for example, in the project by Lau, Chen and colleagues to produce such concordances as Lau and Ching, 1993a, 1993b and Lau and Chen 2000; Kirkland, Barrett, and Kohn, 2000, p. xiv).

\section{Our Approach to the Zhuangzi}

Although none of us are sinologists, we have sought to avoid the dilettantism of much Western writing on "Daoism" (Girardot, 2004; for examples see Davis, 2004; Durlabhji, 2004; Pheng, 2003; Xu, 2006 is something of an exception). First, we have drawn heavily on the writings of specialists. We have also benefited from many generous comments by several of these leading specialists (listed in endnote 1). We have been limited, in our use of detailed commentary, to English language scholars (Mair, 1994a; Roth, 2003a; Wu, 1990). However, the first author's training in Classical Chinese was adequate to read carefully through the passages in question (aided in part by the Wenlin software package; Wenlin Institute, 2002). In so doing he also compared the three excellent, current translations (Graham, 1981, Mair, 1994b, and Watson, 1968) with the Chinese text.

\section{“Effortless Action": An Ultimate Spiritual State}

The first step was to identify key expressions in the passages using Wenlin, print dictionaries, translations and commentaries, guided by Slingerland's (2003) work on central metaphors. These metaphors allude to the spiritual goal common, he claimed, to many writers of this era (compare the critiques by Fraser, 2007 and Ivanhoe, 2007). Like Eno (1996) and Cook (1997), Slingerland focuses on a spiritual ideal that he argues is shared by many 
key texts of the period. Eno (1996, p. 136) expresses this ideal as "the attainment of spontaneous assurance in action through repetitive practice". Slingerland himself expresses it (2003, p. 4) as "an ability to move through the world and human society in a manner that is completely spontaneous and yet still fully in harmony with the normative order of the natural and human worlds - the Dao 道 or “Way." Slingerland's summary expression for this ideal is “effortless action,” or (with Fox, 2003) in Chinese, wu wei 無 爲.

Wu-wei literally means non-action but the literal rendition is misleading. Not all scholars accept Slingerland's "effortless action" but their disagreement is not with the second term - despite the negation $(w u)$, the term does refer to some kind of action (wei). For example, Carr and Ivanhoe (2000, p. 75) refer to "wuwei actions" and Fox (2003, p. 209) to the "effortless activity of the sage." Fraser (2007) takes issue with Slingerland's term in favor of (roughly translated) unmotivated action. In short, the distinctions proposed are fine ones, with the emphasis on lack of "action motivated by the agent's desires, will, ambition" and so on (Fraser, 2007, p. 99), or of "striving" and "action contrary to nature" (Major, 1993, p. 12), or of "artifice" (Coutinho, 2004, pp. 32-33), or of course "effort" (Fox, 2003, p. 209; Ivanhoe, 2007, p. 284; and Slingerland (2003). It is useful to bear in mind this range of possible translations but for simplicity we will use Slingerland's expression.

Because effortless action is regarded as a high spiritual goal, the knack or skill displayed in these passages is not merely instrumental. Rather such skill is "paradigmatic" and its practitioners are "exemplars of the Way" (Ivanhoe, 1993, pp. 643, 644). Thus, sinological scholarship on spirituality pays these parables considerable attention (Cook, 1997; Eno, 1996; Ivanhoe, 1993; Roth, 2003b; Slingerland, 2003; Yearley, 1996.) Moeller and Stan (2003) are skeptical about seeing spirituality or soteriology in the Zhuangzi, but theirs is a minority voice and we hope to demonstrate that their view is mistaken. We agree with Allinson (1989, p. 6) that "spiritual transformation [is] the major, underlying theme of the text", and with Carr and Ivanhoe (2000, p. 58) that the text aims to direct its readers towards "religious fulfillment or salvation." We could agree with Moeller and Stan, however, if Zhuangzi's soteriology were to be construed in typical Western terms. For example, spirituality in the Zhuangzi does not "involve any form of transcendence" (Puett, 2003, p. 256; compare Mitroff and Denton, 1999) but reflects rather an "intrawordly mysticism" that "seeks a way through the world" (Yearley, 1983, p. 131; Allinson, 1989). Because Zhuangzi's spiritual aim is imminent and intrinsic, it should not be confused with "grace" (Carr and Ivanhoe, 2000, p. 72).

\section{The Knack of Worldly Work}


The convergence in the knack passages between mundane affairs and the Dao contrasts with parts of the Zhuangzi itself (the "primitivist" writings of Chapters 8-10 and parts of 11 and 12), with many other period texts such as the Daode Jing (Tao Te Ching), and with "Confucian" writings such as the Mengzi (e.g., IIB, 10 for its distaste for the marketplace, Dobson, 1963, p. 52). The knack passages celebrate worldly activities such as Wheelwright Bian's chiseling a wheel, a hunchback's hunting for cicadas, a ferryman's masterful river crossing, and bell stand-maker Qing's carving. Perhaps the most celebrated and exemplary of these passages is that of Cook (or "Butcher") Ding:

"Cook Ding was cutting up an ox for Lord Wen Hui. At every touch of his hand, every heave of his shoulder, every move of his feet, every thrust of his knee - zip! zoop! He slithered the knife along with a zing, and all was in perfect rhythm, as though he were performing the dance of the Mulberry Grove or keeping time to the Jingshou music.

““Ah, this is marvelous!' said Lord Wen-hui. 'Imagine skill reaching such heights!'

"Cook Ding laid down his knife and replied, 'What I care about is the Way, which goes beyond skill.”" (Watson, 1968, p. 50).

Not just skill but the Way. The second last line is central: what I care about is the Way. This translation by Watson accords with those by Graham and Mair but is disputed in an important book, "A Daoist Theory of Chinese Philosophy" (Hansen, 1992; for reviews see Ames, 1994; Raphals, 1995). Because this phrase is critical and because Hansen's treatment of this passage is the most extensive in his attention to the knack passages (which he largely ignores), we will show that the traditional reading is correct. The phrase in question is chen zhi suo hao zhe dao ye, jin ji ji yi 臣之所好者道也, 進乎技矣. Hansen reads this, “ “what I care about is a dao [i.e., that of butchering] which advances my skill”" (1992, p. 287). Two major changes from the other translations are apparent. Hansen argues that there are multiple daos, and hence reads "a" dao rather than "the" dao. This cannot be resolved from the Chinese itself. Hansen would argue that we cannot resolve any such disputes from the text itself, but we will show that his rendering of the second part of the phrase is implausible.

His second major change is from "goes beyond" to "advances my" skill. The last four characters are (1) a verb for surpass or advance, (2) a coverb (akin to a preposition) meaning to, at, with, than, (3) a noun meaning skill, and (4) a mildly exclamatory particle. Hansen's translation would not do violence to the expression regarding the verb itself out of context, but the verb with its coverb is very hard to interpret his way. Moreover, the only other 
occurrence of these characters (jin ji) in the Zhuangzi (which like the Cook Ding passage appears in a section thought to be by Zhuangzi) can only mean exceeds or surpasses; otherwise it would read 'the ruler's virtue advances his sun" rather than "virtue excels that of the sun" (Mair, 1994b, p. 20; Watson, 1968, p. 45). For other problems with Hansen's multiple daos theory see Slingerland (2003, pp. 275-276).

\section{Alertness as Central to the Knacks}

Heightened perception is implicit in all the knack passages, but most poetically stated regarding the ordinary senses in the story of a hunchbacked cicada catcher. The hunchback tells Confucius (used as a stock character, not the historical figure) that "No matter how large heaven and earth, or how numerous the ten thousand things, I'm aware of nothing but cicada wings. Not wavering, not tipping, not letting any of the other ten thousand things take the place of those cicada wings - how can I help but succeed?' Confucius [extrapolates] 'He keeps his will undivided and concentrates his spirit..." (Watson, 1968, p. 200).

Wood-carver Qing has a goal that is more abstract. In explaining how he creates his marvelous bell stands, he says he will not start working until he finds a complete vision of the finished product latent within a tree (cheng jian 成見). As this implies, the reality observed is not easily perceived. Another way Qing expresses deeper perception is that he “examines [or observes] the heavenly nature [of trees, in this case] (guan tian xing 觀天性). In the ferryman passage, when Confucius says that "a good swimmer... forgets the water" (Watson, 1968, p. 200; wang shui 忘水), he explains his meaning as the transcendence of external appearances (compare Slingerland, 2003, p. 187). By contrast, he adds, “whoever gives weight to what is outside him is inwardly clumsy” (zhuo 拙, as above; Graham, 1981, p. 137; fan wai zhong zhe nei zhuo 凡外重者內拙).

An alert spirit. The spiritual dimension to alertness is apparent in these passages. So much so that Zhuangzi's theme of "“respond with awareness" is an imperative which... seems trivial; it comes as a surprise that a whole philosophy of life can be based on it" (Graham in Roth, 2003, p. 166). While this might be surprising, awareness for Zhuangzi can only be understood as spiritual. In the words of Wheelwright Bian, the knack of cutting the wood is something "you can get in your hand and feel in your [heart-]mind" (Watson, 1968, p. 153; de zhi yu shou 得之於手... ying yuxin 應於心). Hands and heart-minds are noted, not eyes and ears. Cook Ding contrasts his current practice, in which "I... don't look with my eyes" (Watson, 1968, p. 51) with the approach he 
once used as a novice. Moreover, the heart-mind must first be prepared. Before carver Qing scouted for the right tree he first would fast in order to still [jing] his heart-mind (zhai yi jing xin 齋以靜心).

Preconceptions and cultural baggage are blockages from awareness of the Dao. Qing explains that "“after fasting for three days, I no longer presume to harbor [or cherish: bu gan huai: 不敢懷] any thoughts of congratulations and rewards... After five days... of censure or praise... After... seven days... of public affairs or the court... my skill is concentrated and all external distractions disappear"' (Mair, 1994, p. 183). For transcendence of the culture of power as basic to Zhuangzi’s "religious ethics”, see Møllgaard (2003; also Slingerland, 2003, pp. 275276.)

What is valued then is activity, not outcome (Yearley, 1996). This focus on experience, decoupled from the social environments, was noted millennia later by psychologist Mihaly Csikszentmihali in his work on the "flow experience" ("a harmonious, effortless state", 1990, p. 40; for the characteristics and contexts of this state, see pp. 47-70; compare also the state of "running hot" in entrepreneurial teams, Stewart, 1989). Csikszentmihali makes the parallel explicit by his discussion of the Cook Ding passage (1990, pp. 150-151; thanks to P.J. Ivanhoe and Ted Slingerland for this analogy). Similarly "Confucius" explains the ferryman's abilities by noting that those who compete for stakes of [only] tiles are skillful (yi wa zhu zhe qiao 以瓦注者巧; Mair 1994a, pp. 44-45).

Not only do external distractions disappear, so too does the “self” (si 私). The old swimmer, who jauntily flows through rapids far too disturbed and dangerous for fish, expresses it this way: he does not impose himself $(b u$ wei si 不爲私) on the water (Mair, 1994, p. 182; Slingerland, 2003, p. 180; compare the Nameless Man: Watson, 1968, pp. 93-94; Lau and Chen, 2000, p. 20). The Zhuangzian paragon is "Dao-centered", not "ego-centered" (Roth, 2003b, p. 26).

Alertness derives not from the senses but directly from the spirit (shen 神), or as Graham translates, “the daemonic" (Lin, 2003, p. 275; shen are natural spirits as distinct from human spirits or ghosts). A clear statement of transformation to this alertness is in the Cook Ding passage. Cook Ding, we noted, no longer looks at the ox with his eyes. Rather, “"perception [of organs] and understanding have come to a stop (guan zhi zhi 官知止) and spirit moves where it wants"” (Watson, 1968, p. 51; shen yu xing 神欲行). The Zhuangzi is unusual in classical Chinese for its aversion to repeating stock terms, but it makes many uses of “shen”. [2] For example, Cook Ding “"is in touch [with the ox] through the daemonic in me"” (yi shen yu 以 神 遇, Graham. 1981, p. 63); “the ferryman handled 
the boat like a spirit” (ruo shen 若神, Mair, 1994, p. 177); “when [carver Qing's] bell stand was completed, all who saw it were as amazed as though they were seeing the work of a spiritual being” (you gui shen 猶鬼神, Mair, 1994, p. 182). Zhuangzi's references to shen and to mystical states might have been motivated by "inner cultivation practices" involving breathing techniques (Roth, 2003b, p. 17) but the evidence is weak (Carr and Ivanhoe, 2000, pp. 64-71, 137).

\section{A Knack for Entrepreneurship}

The passages that we have so far discussed all refer to ordinary worldly work or athletics. Loosely construed, they can be seen as akin to the "craftsman" type of entrepreneur (Smith and Miner, 1983) but these parables are not distinctively entrepreneurial. Only one passage in the Zhuangzi is. But this is an important passage with considerable detail. It also appears in Chapter One and is one of only two knack passages that likely were written by Zhuangzi himself. In this passage a traveler trades pieces of gold to a family of silk bleachers in exchange for the proprietary formula for a hand balm, which he takes to another small state. Once there he uses it to win a maritime battle in winter conditions, for which he is rewarded with a fief. Zhuangzi finds this praiseworthy. The silk bleachers had used the balm only to prevent chapping in low-profit work (as they themselves note in the passage), but the traveler saw an opportunity for technology transfer and arbitrage (as we would construe it). Zhuangzi commends the traveler's practical knowledge (yong): “ze suo yong zhi yi 則所用之異也: [what it can do is the same but] it was put to different uses."

For some sinologists such as Allinson (1989, pp. 47-50) this passage is a metaphor for cognitive processes, but business scholars will be struck by how well this trader exemplifies "opportunistic" entrepreneurship (Smith and Miner 1983) as theorized by “Austrian school” economists (Kirzner, 1973: 198), by sociologists such as Burt (1992), and anthropologists such as Barth (1967). In these approaches, opportunities for profit are generated by discrepancies of evaluation across social and cultural boundaries, geographic distance, or time. As the Austrian economists emphasized, in order to capitalize on such an opportunity, astute traders had first to recognize it exists, to be "alert". The trader's alertness is depicted only implicitly, but the character of "Zhuangzi" in the same passage criticizes his “favorite philosophical sparring partner", Huizi, for his non-alertness (Carr and Ivanhoe, 2000, pp. 4, 14-15; Mair, 1994a, p. 2). Huizi is chastised for still having clumps of grass (peng 蓬) in his heart-mind (xin 心), 
because he failed to “consider using” (lü yi wei 盧 以爲) a large gourd for a non-obvious purpose (a float to use for traveling in waterways). For this Huizi is labeled "clumsy" (zhuo 拙) - the opposite of "effortless action".

Why are people like Huizi not alert? One answer is "Zhuangzi's" exasperated reply to an interrogator who skeptically demands, where exactly is this so-called The Way? After adducing a series of more and more modest locations, Zhuangzi silences his interlocutor with, “It’s in piss and shit!” (zai shi niao 在 屎 溺; this is the literal translation by Mair, 1994b, p. 217; see 1994a, p. 57). Zhuangzi concludes, "Your questions, sir, do not get at the substance of the matter" (wen... bu ji zhi 問... 不及質). Little imagination is required to think of people who fail to see opportunities in such places or of entrepreneurs finding profit in places that others overlook. Still, this does not answer why some people have clumps of grass in their heart-brains and others not. Presumably one reason is that cultures discourage people from close attention to some topics, including the natural world (Needham, 1956, p. 47). Similarly, cultures may stigmatize the very people most attuned to the Dao. As Carr and Ivanhoe (2000, p. 35) observe, "Zhuangzi's heroes are more "underheroes" than antiheroes: butchers, boatmen, and buckle makers ... and hump-backed [commoners]. Almost everything about them... makes them underappreciated, even outcasts in their own society." As Coutinho (2004, Chaps. 4, 8) argues, the Zhuangzi challenges the reader to see beyond parochial perspectives and to appreciate vast possibilities, to be alert to betwixt-and-between and anomalous opportunities.

\section{The Paradox of Effortless Action}

On reflection, these passages suggest a paradox: how does one try not to try? As Cook (1997, p. 524) puts it, "the fundamental paradox [is] between the hardship and incessant discipline of constrained practice... and the spontaneous freedom of performance or the perfect embodiment of artistry." As Slingerland argues, the "paradox" of this spiritual state is that one needs to strive to be able to not strive. "The state of effortless, perfected action represented by wu-wei is portrayed as a state that needs to be achieved: we are currently not practicing wu-wei, and the thinkers [including Zhuangzi] propose various soteriological paths designed to bring us from our current state of 'effortful' action into this ideal state of effortless action" (2003, p. 6). Certainly if wuwei refers to something like unmotivated action, as implied by the archery prizes metaphor, there does seem to be a paradox, or at the least a "puzzle". (Ivanhoe, 2007, prefers this latter term because it implies neither that there is no resolution nor that the resolution is largely cognitive; compare also Carr and Ivanhoe, 2000, pp. 59, 71-72; for criticism of the concept, Fraser, 2007.) 
We touch on only two of the Zhuangzi's approaches for resolving this paradox as proposed by Slingerland (2003, pp. 210-215). First, as the many allusions to shen suggest, a resolution might be trust or faith. "Zhuangzi's thought [is] religious in that it is essentially founded upon an unbounded faith in the natural Way" (p. 213). Second, Zhuangzi also recognized "that we $d o$ in fact have to try not to try - that is, that wu-wei represents the culmination of a long period of training” (p. 212). Slingerland drew on the work of the Japanese scholar Mori Mikisaburo in noting that this resolution does not apply to the more contemplative spiritual states depicted in the Zhuangzi, but it does apply to what Mori called “'activity naturalness' [which] can be acquired through training” (p. 211).

Zhuangzi's "Confucius" character claims that one "can learn [as in studying]" to be as skilled as the ferryman (ke xue 可學); that one can achieve such a skill (shu neng 數能). Many of the effortless exemplars refer to prior years of effort. The most explicit of these attributions is the cicada catcher's tale of practicing balancing more and more balls on the end of a stick. Even the usually spontaneous Cook Ding has to slow down and learn, momentarily, how to "resolve (jie [解] - also separate, divide) the complexities... (zu[族])" of a difficult spot (Wu, 1990, pp. 321-323, 324 for quote; Roth, 2003a, p. 162). One reason time is needed is that the skills to be learned are tacit skills; as Wheelwright Bian puts this “you can’t put it in words, but there's a knack” (bu neng yan, you shu: 不 能言, 有數). Moreover, what is practiced is giving up of the self and following instead the innate and the Dao.

Effortless action and goal striving. The paradox of effortless action is echoed in recent research on goal striving in psychology and management literatures. Goal striving refers to the ways people manage their thoughts and actions while working towards a desired outcome (Diefendorff, Hall, Lord and Strean, 2000; Gollwitzer and Brandstätter, 1997). Research in this tradition focuses on the factors that affect the successful pursuit of goals over time. In contrast to most "goal theories [which] typically...examine how one can efficaciously pursue goals," studies of goal striving examine "why one pursues particular goals and/or the significance of what specific goals are pursued" (Ryan, Sheldon, Kasser and Deci, 1996, p. 7). These studies show, for example, that people are happier and more effective when the goals they pursue are consistent with their values, ideals and interests, as opposed to extrinsic rewards such as admiration or wealth (Judge, Bono, Erez and Locke, 2005; Sheldon and Elliot, 1999). If they take the former approach, they may experience their work as effortless despite its apparent difficulties.

\section{The Meaning of Following the Way}

Because the knack protagonists give up their self for the Dao, many of them deny possessing any skill. Cook Ding's response to the aristocrat's appreciation of “skill attaining such [heights]” (ji gai zhi ci 技蓋至此) is 
that what Ding cares about is the Way, which goes beyond skill (dao... jin hu ji 道... 進乎技). When Qing the carver is asked about the “art” by which his stand was made (shu yi wei 術 以爲) he denies having any such art. When the cicada catcher is asked if he is clever (skilled) or if he has the Way, he replies the latter (qiao [contrasted with] you dao 巧有道; similar phrasing is found in the buckle maker passage).

The swimmer replies to a similar question revealingly: "I do not have the Way" ( wu wu dao 吾 無道). It turns out that by this he means the Way is not his; he submits himself to it: "I follow the Way of the Water" (cong shui zhi dao 從水之道). His example is also interesting for paralleling a paradox about entrepreneurs, how they can appear so relaxed and even, like the swimmer who sings beside the torrent, blasé, when to outside observers they seem to be headed for certain ruin (Cooper, Woo, and Dunkelberg, 1988). One reason has been suggested: they are interested in the game of business itself, and not external outcomes. Another, offered by the swimmer, is that their actions seem easy because their preparation, their practice, has been natural and life-long. He explains to Confucius, “I began with what was innate, ( $s h i h u g u$ 始乎故), grew up with my nature (zhang hu xin 㫳乎性), and completed my destiny (cheng hu ming 成乎 命)... I was born among these hills and feel secure among them that's what's innate. I grew up in the water and feel secure in it - that's my nature. I do not know why I am like this, yet that's how I am - that's my destiny” (Mair, 1994, p. 182; compare Bulger, 2002; Ronstadt, 1988).

The reward for this preparation and loss of preconceptions is “not”, Ivanhoe (1993, p. 646) notes, “a confrontation with the abyss" but an ability to harmonize one's internal spirit with the Dao. It is an ability to attune one's spirit to that of Heaven (tian 天; for the near-equivalence of dao and tian see Slingerland, 2003, pp. 177, 200203; for shen and tian see Puett, 2003). As Cook Ding says, “I rely on Heaven's structuring” (yi hu tian li 依乎天 理), “following what is inherently so" (yin qi gu ran 因其固然; Roth, 2003a, p. 78). Carver Qing puts this point similarly: he “joins Heaven to what is Heaven's" (tian he tian 天 合天; he matches his innate nature with that of the tree; Graham, 1981, p. 135). These quotations suggest that Slingerland was right in arguing that ultimately Zhuangzi's vision is founded on faith. By the same token, this faith in the encounter between the prepared spirit and the world as it is can be seen as "not irrational or 'mysterious' at all, but... rather 'perfectly rational' (i.e., it accord[s] with the objective structure of reality" [Slingerland, 2003, p. 321, n. 79]).

In the eclectic, occasionally Daoist text the Huainanzi (c. 139 B.C.E.), we find this explication: "It is difficult for the person taking the lead to be wise, while it is easy for the one coming behind to achieve results (xian 
zhe nan wei zhi, er hou zhe yi gong ye 先者難爲知, 而後者易爲攻也)... By 'coming behind' is not meant being stagnant, numb and inert. Rather, it means putting store in always being in accord with that which is necessarily so, and being appropriate to the moment" (Lau and Ames, 1998, p. 99).

\section{Appropriating Ancient Texts: Dangers in Going "Daoist"}

With a work as subtle as the Zhuangzi, readers will take from it multiple meanings. It is natural that scholars dispute how to interpret it, and we encourage readers to follow up with our references for approaches that differ from ours. Unfortunately it is also easy to imagine a careless appropriation of projected meanings into an eclectic, Westernized "Daoism". We do not deny the possibility of a Western mode of such a religion, or any religions from very different cultures (Miller, 2003; Jenkins, 2004, pp. 245-255; for the Chinese history of multiple religious belonging see Brook, 1993). However, we caution against a dilettantish Daoism which militates against a full appreciation of these passages. Such a Daoism has found a place in New Age Management writings (Davis, 2003; Durlabhji, 2004; Pheng, 2003; even Chia, 2003 is far from above reproach).[3] The Zhuangzi passages are incompatible with the easy spirituality by which some Americans appropriate and “"play' with the religions of the world" (El-Zein, 2000, p. 71; see also p. 83; Phan, 2003).

Two reasons for caution are apparent. The first is that equating the Zhuangzi with other "Daoist" works results in confusion. (For the contested, messy boundaries of Daoism, see Graham, 1990; Miller, 2003; Kirkland, 2004; Kirkland et al., 2000.) Confusion of this sort is apparent in longstanding efforts to assimilate the Zhuangzi to the tradition of the Daode Jing (conventionally the two classics of Daoism; see Slingerland, 2003, p. 286). The Daode Jing (道德經) opposes (at least for common people) not only desire and profit, but also beautifully crafted possessions (such as Qing's bell stand); not only knowledge ( $z h i$ 知) but also skill (qiao 巧; see “Chapters" 3, 9, 19, 46, 53, 57, 64, 65 of the Daode Jing; Lau, 1982, pp. 202-203, 212-214, 220-223, 232-235, 236-237, 268-271, 276278, 292-293). So too do the "primitivist" chapters in the Zhuangzi itself (see Chapters 9 and 10), and texts from priestly Daoism of a later date (Bokenkamp, 1997; Kohn, 1993, pp. 96-97, 130-131). None of these other texts discusses knack, except to find fault (in the "primitivist" chapters mentioned). The clearest depiction (in Chapter 15) of a high spiritual state in the Daode Jing is vague at best. Moreover, it is not possible to read the work closely without recognizing an elitist orientation (clearest in Chapters 15 and 41). This work, favored in bookstores worldwide (Chan, 2000), can reasonably be understood as "an ideological justification for a ruthless, totalitarian 
government" (Paper, 2001, p. 109; see Chap. 5; for translations, minimizing this interpretation, see Lau, 1982, pp. 272-273, 192-195, 286-289).

The second reason for caution is found in the passages themselves. We have noted the rarity of achieving the highest spiritual state. For example, the old swimmer cautions us: I was born among these hills and feel secure among them - that's what's innate. I grew up in the water and feel secure in it - that's my nature. I do not know why I am like this, yet that's how I am - that's my destiny." It is not easy for people not so born to learn to swim in those Daoist waters.

\section{Some Tentative - Tenuous ( $x u$ 虛) - Suggestions}

The variant of the cicada-catcher passage found in the Liezi also offers a caution: "Confucius" responds with a summary: "'set your will on one aim, and be equal to the gods." But the cicada-catcher will have none of this glibness. "“What do you think you know about it? Sweep away these principles of yours before you talk about it again"” (Graham, 1990, p. 45). Although we are chastened by this warning, we follow our scholarly traditions in suggesting implications. Before we do this, we try to summarize the meaning of spirituality for the knack passages. Risking both over-simplification and verbosity at once, "spirituality" refers to the process of personal transformation (hua) of the heart-mind (xin) so as to attain the alertness needed for wu-wei or "effortless" (or graceful but not Graced) action within in the natural universe (tian) (Allinson, 1989; Carr and Ivanhoe, 2000; Slingerland, 2003). This universe is presumed to include natural spirits (shen) (Puett, 2003) but this appears not so essential to understanding Zhuangzi's spirituality as the former points are.

One implication of studying the Zhuangzi is that the metaphors of these passages may suggest a language better suited to the activities and mindsets of artisans and entrepreneurs than conventional Management terminology. Entrepreneurship certainly is not conveyed well by language drawn from fields such as economics, structural functional sociology, and operations research. Some years ago, Mulligan (1987) proposed that business schools take the language of the humanities more seriously. This study of Zhuangzi is one way of following his suggestion.

Zhuangzi's language is helpful not only for its literary qualities, but for its examination of the spiritual dimensions of work.

A second implication is to reconsider the character of "knowledge" in business schools. "For Chuang-tzu [Zhuangzi] the fundamental error is to suppose that life presents us with issues which must be formulated in words so that we can envisage alternatives and find reasons for preferring one to the other" (Graham, 1981, p. 6; also Chap. 
5). This error is routine in business school thinking (Sarasvathy, 2001). However, as we have seen, the error lies not in intense mental functioning; it lies in preconceptions and "knowledge", but not in alertness (compare Kirzner's depiction of entrepreneurial activity [1973, pp. 67-68]; this is perhaps why we, as highly schooled professionals, may be baffled each time we observe poor students turning into good entrepreneurs). Error lies also in rendering the implicit as explicit - the lesson of Wheelwright Bian. Error lies in showering attention on prestigious firms, forgetting that new wealth is found elsewhere, in "piss and shit".

\section{The Paradox of (Non) Instrumentality}

A third implication we call the "paradox of (non)instrumentality". Sinologists have been alert to the paradox of effortless action but less so to a related conundrum. If the whole story were one of effortless action, conveyed by metaphors such as loss of "self", unconcern for worldly aims or control, and "mirror-like" "responsiveness" (Carr and Ivanhoe, 2000, p. 38; Puett, 2003; Slingerland, 2003, p. 192) we would expect to find a celebration of action for its own sake. Yet we do find instrumental outcomes. The paragons' actions are not "undirected" (contrary to Chia, 2003) or "useless" (contrary to Cook, 1997). Outcomes include the successful butchering of an ox (probably for a ceremony), taxes raised (probably for a set of public bells), captured delicacies (cicadas), passengers ferried, a wonderful bell stand, a cart wheel, and a buckle (or hook), not to mention a profitable trade and victory in a battle. Instrumental ends did materialize despite being apparently ignored. As Fox (2003, p. 218) points out, the "genuine person... is not 'purposeless' [and] though a river may meander, following the path of least resistance, it still always manages to get to the sea." The "spontaneous" does not lack intentionality (Carr and Ivanhoe, 2000, p. 38). The message of the Zhuangzi may be "mystical", but its mysticism is “"intraworldly”" and "extrovertive” (Roth, 2003b, pp. 17, 29; Yearley, 1983, p. 131).

One resolution of this paradox - ignore instrumentality but still get what you desire - is that only certain outcomes are consistent with the Dao. Ivanhoe argues that "Zhuangzi's examples of skillful individuals... all [engage in] quite benign activities. There are no skillful assassins or pickpockets among" them (1993, p. 651; also Carr and Ivanhoe, 2000, pp. 41, 71-75). From the perspective of entrepreneurs, the Zhuangzi implies that only certain opportunities are consistent with the Way. Only some opportunities, perhaps, but they are myriad, unpredictable, and available for the truly attentive. After all, some might question the Dao in piss and shit, or the Way of the tax collector (even if the taxes would yield a public good); some might question the trader's efforts in battle. The Zhuangzi is catholic and ecumenical here. 
We ought not, then, rule out the possibility of entrepreneurs reading the Zhuangzi as a practical text. P.J. Ivanhoe has argued (personal communication), "I would not... discount the advantages his way offers for both productivity and creativity. While one is not supposed to aim at these goals directly, the Daoist Way does promise one such prosaic ends as well as a more satisfying life." One possible "lesson", for example, is this: to accomplish practical results ignore them and attend to the flow of activities; if you insist on thinking about goals, think only about non-instrumental goals. Such a paradoxical approach anecdotally accords with accounts by successful entrepreneurs (Komisar, 2000) and with research findings on spiritual motivations and their effect on entrepreneurial success (above). Such an approach also accords with research on goal orientation theory.

Goal orientation theory (Elliot and Church, 1997; VandeWalle, Brown, Cron and Slocum, 1999) defines two qualitatively distinct patterns: mastery oriented goals and performance oriented goals. Mastery goals focus on skills development and efforts to attain personal standards of accomplishment. People who seek mastery goals tend to become absorbed in their chosen activities and to persist energetically in the face of obstacles. These goals direct attention towards the process of developing their capacities rather than towards particular outcomes. By contrast, performance goals are outcome oriented and focus attention on demonstrations of competence and the acquisition of extrinsic rewards. Despite these intentions, a focus on performance goals does not always result in goal achievement. The external orientation leads to distractions from skill development (VandeWalle et al., 1999). Mastery goals, of the sort represented in the Zhuangzi, often lead indirectly to desirable outcomes because they encourage long-term learning of task-related skills.

\section{By Way of a Conclusion}

In management writing the norm is to conclude by noting the many limitations of our work (and indeed they are galling, not least the difficulty of defining Zhuangzi’s "spirituality"), but also by puffing up our accomplishments, and calling of course for more research, perhaps on better defining spirituality, perhaps on the causality amongst variables such as spiritual motivations and entrepreneurial success. Such a conclusion would violate the spirit of the Zhuangzi. Therefore we close with a call to learn how to live like Cook Ding, like the swimmer, like the cicada-catcher, like the balm-buyer, like wheelwright Bian. The Zhuangzi calls us not just to think about or to write about the highest spiritual states, but also to act, to live our lives in these states as best we can (see also Cornwall and Naughton, 2003 for a similar Catholic argument). This is a reason for the interest that many find in classical Chinese thought, which is oriented not to the question of "what is good" but "how to be good" (Ivanhoe, 
1993; Roth, 2003a, p. 163; Slingerland, 2003, p. 3). Of course, how to be good in practice, for scholars, means how to be good in scholarship. Insofar as our reflections on the Zhuangzi have any impact on scholarly action, we hope they inspire more and deeper attention to this text. We hope that some management spirituality scholars will also read in the scholarly literature on these texts, which we have tried to introduce. We hope that some will find their opportunities in classical Chinese thought.

"The right moment becomes the wrong

Before one can take a breath.

One who acts too soon anticipates the opportunity,

And one who acts too late gets left behind.

The sun revolves, the moon wheels its course,

And the right moment waits for no man.” (Lau and Ames, 1998, p. 101). 


\section{References}

Allinson, R. E. (1989) Chuang-Tzu for Spiritual Transformation: An Analysis of the Inner Chapters. Albany, NY: State University of New York Press.

Ames, R. T. (1994) Review of A Daoist Theory of Chinese Thought: A Philosophical Interpretation, Harvard Journal of Asiatic Studies, 54(2), 553-561.

Barth, F. (1968) Economic spheres in Darfur, In R. Firth (Ed) Themes in Economic Anthropology, London: Tavistock, pp.149-174.

Bell, E., and Taylor, S. (2004) "From outward bound to inward bound": The prophetic voices and discursive practices of spiritual management development, Human Relations, 57(4), 439-466.

Benefiel, M. (2003) Mapping the terrain of spirituality in organizations research, Journal of Organizational Change Management, 16(4), 367-377.

Biberman, J., and M. D. Whitty (Eds) Work and Spirit: A Reader of New Spiritual Paradigms for Organizations, Scranton, PA: University of Scranton Press.

Bokenkamp, S. R. (1997) Early Daoist Scriptures. Berkeley, CA: University of California Press.

Brook, T. (1993) Rethinking syncretism: The unity of the Three Teachings and their joint worship in late-Imperial China, Journal of Chinese Religions, 21(3), 13-44.

Bulger, G. (2002) The Enlightened Entrepreneur: A Spiritual Approach to Creating and Marketing a Company. New York, NY: Marlowe and Company.

Burt, R. S. (2002) Structural Holes: The Social Structure of Competition. Cambridge, MA: Harvard University Press.

Carr, K. L., and Ivanhoe, P. J. (2000) The Sense of Anti-Rationalism: The Religious Thought of Zhuangzi and Kierkegaard. New York, NY: Seven Bridges Press.

Chan, A. (2000) The Daode jing and its tradition, In L. Kohn (Ed) Daoism Handbook, Leiden: Brill, 1-29.

Chia, R. (2003) From knowledge-creation to the perfecting of action: Tao, Basho and pure experience as the ultimate ground of knowing, Human Relations, 56(8), 953-981.

Cook, S. (1997) Zhuangzi and his carving of the Confucian ox, Philosophy East \& West, 47(4), 521-553.

Cooper, A. C., Woo, C. Y., and Dunkelberg, W. C. (1988) Entrepreneurs' perceived chances for success, Journal of Business Venturing, 3(2) 97-108. 
Cornwall, J. R., and Naughton, M. J. (2003) Who is a good entrepreneur? An exploration within the Catholic social tradition, Journal of Business Ethics, 44(1), 61-75.

Coutinho, S. (2004) Zhuangzi and Early Chinese Philosophy: Vagueness, Transformation, and Paradox. Aldersot, Hants, UK: Ashgate.

Csikszentmihalyi, M. (1990) Flow: The Psychology of Optimal Experience. New York, NY: Harper \& Row.

Davis, D. D. (2004) The tao of leadership in virtual teams, Organizational Dynamics, 33(1), 47-62.

Diefendorff, J. M., Hall, R. J., Lord, R. G., and Strean, M. L. (2000) Action state orientation: Construct validity of a revised measure and its relationship to work-related variables, Journal of Applied Psychology, 45(2), 250263.

Dobson, W. A. C. H. (1963) Mencius: A New Translation Arranged and Annotated for the General Reader. Toronto, ON: University of Toronto Press.

Durlabhji, S. (2004) The tao of organizational behavior, Journal of Business Ethics, 52(4), 401-409.

El-Zein, A. (2000) Spiritual consumption in the United States: The Rumi phenomenon, Islam and Christian Muslim Relations, 11(1), 71-85.

Elliot, A. J., and Church, M. A. (1997) A hierarchical model of approach and avoidance achievement motivation, Journal of Personality and Social Psychology, 72(1), 218-232.

Eno, R. (1996) Cook Ding's Dao and the limits of philosophy In P. Kjellberg and P. J. Ivanhoe (Eds) Essays on Skepticism, Relativism, and Ethics in the Zhuangzi, Albany, NY: State University of New York Press, $127-151$

Fornaciari, C., and Lund Dean, K. (2001) Making the quantum leap: Lessons from physics on studying spirituality and religion in organizations, Journal of Organizational Change Management, 14(4), 335-351.

Fox, A. (2003) Reflex and reflexivity: Wuwei 無爲 in the Zhuangzi, In S. Cook (Ed) Hiding the World in the World: Uneven Discourses on the Zhuangzi, Albany, NY: State University of New York Press, 207-225.

Fraser, C. (2007) On wu-wei as a unifying metaphor, Philosophy East and West, 57(1), 97-106.

Fuller, M. A. (1999) An Introduction to Literary Chinese. Cambridge, MA: Harvard University Press.

Giacolone, R. A., and Jurkiewicz, C. L. (Eds) (2003) Handbook of Workplace Spirituality and Organizational Performance. Armonk, NY: M. E. Sharpe.

Girardot, N. J. (2004) Foreword, In R. Kirkland, Taoism: The Enduring Tradition, New York, NY: Routledge, vii-X. 
Gollwitzer, P., M., and Brandst ätter, V. (1997) Implementation intentions and effective goal pursuit, Journal of Personality and Social Psychology, 73(1), 186-199.

Graham, A. C. (Trans.) (1990) The Book of Lieh-tzu: A Classic of Tao. New York, NY: Columbia University Press.

Graham, A. C. (Trans.) (1981) Chuang Tzu: The Seven Inner Chapters and Other Writings from the Book Chuangtzu. Boston, MA: Allen \& Unwin.

Hansen, C. (1992) A Daoist Theory of Chinese Philosophy: A Philosophical Interpretation. New York, NY: Oxford University Press.

Hansen, C. (2003) Guru or skeptic? Relativistic skepticism in the Zhuangzi, In S. Cook (Ed) Hiding the World in the World: Uneven Discourses on the Zhuangzi, Albany, NY: State University of New York Press, 128-162.

Harrington, W. J., Preziosi, R. C., and Gooden, D. J. (2001) Perceptions of workplace spirituality among professionals and executives, Employee Responsibilities and Rights Journal,13(3), 155-163.

Heaton, D. P., Schmidt-Wilke, J. and Travis, F. (2004) Constructs, methods and measures for researching spirituality in organization, Journal of Organizational Change Management, 17(1), 62-82.

Ivanhoe, P. J. (1993) Zhuangzi on skepticism, skill, and the ineffable Dao, Journal of the American Academy of Religion, 61(4), 639-654.

Ivanhoe, P. J. (2007) The paradox of wuwei? Journal of Chinese Philosophy, 34(2), 277-285.

Jenkins, P. (2004) Dream Catchers: How Mainstream America Discovered Native Spirituality. New York, NY: Oxford University Press.

Judge, T. A., Bono, J. E., Erez, A., and Locke, E. A. (2005) Core self-evaluations and job and life satisfaction: The role of self-concordance and goal attainment, Journal of Applied Psychology, 90(2), 257-268.

Katz, J. A. (1994) Modeling entrepreneurial career progressions: concepts and considerations, Entrepreneurship Theory and Practice, 19(2), 23-39.

Kinjerski, V. M. and Skrypnek, B. J. (2004) Defining spirit at work: finding common ground, Journal of Organizational Change Management, 17(1), 26-42.

Kirkland, R. (2004) Taoism: The Enduring Tradition. New York, NY: Routledge.

Kirkland, R., Barrett, T. H., and Kohn, L. (2000) Introduction, In L. Kohn (Ed) Daoism Handbook, Leiden: Brill, xiXxxviii.

Kirzner, I. M. (1973) Competition and Entrepreneurship. Chicago, IL: University of Chicago Press. 
Kohn, L. (1993) The Taoist Experience: An Anthology. Albany, NY: State University of New York Press.

Kolvereid, L. (1996) Prediction of employment status choice intentions, Entrepreneurship Theory and Practice, 21(1), 47-72.

Komisar, R. (2001) The Monk and the Riddle: The Art of Creating a Life while Making a Living. Cambridge, MA: Harvard Business School Press.

Konz, G. N. P., and Jackson, J. J. (2002) Spirituality in entrepreneurial enterprises: A preliminary audit, Business Research Yearbook, 9, 445-450.

Krishnakumar, S., and Neck, C. P. (2002) The 'what', 'why' and 'how' of spirituality in the workplace, Journal of Managerial Psychology, 17(3), 153-164.

Lau, D. C. (Trans) (1982) Tao Te Ching: A Bilingual Edition. Hong Kong: Chinese University Press.

Lau, D. C. and Ching, C. F. (Eds) (1993a) Huainanzi Zhuzi Suoyin: Concordance to the Huainanzi. Hong Kong: Commercial Press.

Lau, D. C. and Ching, C. F. (Eds) (1993b) Liezi Zhuzi Suoyin: Concordance to the Liezi. Hong Kong: Commercial Press.

Lau, D. C., and Chen, F. C. (Eds) (2000) Zhuangzi Zhu Zi SuoYyin: Concordance to the Zhuangzi. Hong Kong: Commercial Press.

Lau, D. C., and Ames, R. T. (Trans) (1998) Yuan Dao: Tracing Dao to its Source. New York: Ballantine.

Lin, S.-F. (2003) Transforming the Dao: A critique of A. C. Graham's translation of the inner chapters of the Zhuangzi, In S. Cook (Ed) Hiding the World in the World: Uneven Discourses on the Zhuangzi, Albany, NY: State University of New York Press, 263-290.

Lips-Wiersma, M. (2002) The influence of spiritual "meaning-making” on career behavior, Journal of Management Development, 21(7/8), 497-520.

Mair, V. H. (1994a) Introduction and notes for a complete translation of the Chuang Tzu, Sino-Platonic Papers, 48, i-xxxiv, 1-110.

Mair, V. H. (Trans) (1994b) Wandering on the Way: Early Taoist Tales and Parables of Chuang Tzu. New York, NY: Bantam.

Mair, V. H. (2000) The Zhuangzi and its impact, In L. Kohn (Ed) Daoism Handbook, Leiden: Brill, 30-52.

Major, J. S. (1993) Heaven and Earth in Early Han Thought. Albany, NY: State University of New York Press. 
Miller, J. (2003) Daoism: A Short Introduction. Oxford, UK: Oneworld.

Mitroff, I. I. (2003) Do not promote religion under the guise of spirituality, Organization, 10(2), 375-390.

Mitroff, I. I., and Denton, E. A. (1999) A Spiritual Audit of Corporate America: A Hard Look at Spirituality,

Religion and Values in the Workplace. San Francisco, CA: Jossey-Bass.

Moeller, H.-G., and Stan, L. (2003) On Zhuangzi and Kierkegaard, Philosophy East and West, 53(1), $130-135$.

Møllgaard, E. (2003) Zhuangzi's religious ethics, Journal of the American Academy of Religion, 71(2), 347-370.

Morgan, E. (Trans) (1969, originally c. 1933) Tao the Great Luminant: Essays from Huai Nan Tzu. New York, NY: Paragon Book Reprint Co.

Mulligan, T. M. (1987) The two cultures in business education, Academy of Management Review, 12(4), 593-599.

Needham, J. (1956) Science and Civilization in China, Vol. 2: History of Scientific Thought. Cambridge, UK:

Cambridge University Press.

Paper, J. (1995) The Spirits are Drunk: Comparative Approaches to Chinese Religion. Albany, NY: State University of New York Press.

Paper, J. (2001) Chinese religion, "Daoism”, and deep ecology, In D. L. Barnhill and R. S. Gottlieb (Eds) Deep ecology and world religions, Albany, NY: State University of New York Press, 107-126.

Pauchant, T. C. (2002) Ethical and spiritual management addresses the need for meaning in the workplace, In T. C. Pauchant (Ed) Ethics and spirituality at work, Westport, CT: Quorum, 2-27.

Phan, P. C. (2003) Multiple religious belonging: Opportunities and challenges for theology and church, Theological Studies, 64(3), 495-519.

Pheng, L. S. (2003) Lessons from Lao Tzu’s Tao Te Ching for the facilities manager, Facilities, 21(11/12), $280-288$.

Puett, M. J. (2003) "Nothing can overcome Heaven": The notion of spirit in the Zhuangzi, In S. Cook (Ed) Hiding the world in the world: Uneven discourses on the Zhuangzi, Albany, NY: State University of New York Press, 248-262.

Raphals, L. (1995) A language theory of Chinese thought, The Journal of Religion, 75(1), 80-89.

Ronstadt, R. (1988) The corridor principle, Journal of Business Venturing, 3(1), 31-40.

Roth, H. D. (1993) Chuang tzu, In M. Loewe (Ed) Early Chinese Texts: A Bibliographical Guide, Berkeley, CA: The Society for the Study of Early China, 56-66. 
Roth, H. D. (Ed.) (2003a, originally 1981) A Companion to Angus C. Graham's Chuang Tzu [text largely by Graham]. Honolulu, HI: University of Hawai’i Press.

Roth, H. D. (2003b) Bimodal mystical experience in the qiwulun 齊物論 chapter of the Zhuangzi 莊 子, In S. Cook (Ed) Hiding the World in the World: Uneven Discourses on the Zhuangzi, Albany, NY: State University of New York Press, 15-32.

Ryan, R. M., Sheldon, K. M., Kasser, T., and Deci, E. L. (1996) All goals are not created equal: An organismic perspective on the nature of goals and their regulation, In P. M. Gollwitzer and J. A. Bargh (Eds) The Psychology of Action: Linking Cognition and Motivation to Behavior, New York, NY: Guilford Press, 7-26.

Sarasvathy, S. D. (2001) Causation and effectuation: Towards a theoretical shift from economic inevitability to entrepreneurial contingency, Academy of Management Review, 26(2), 243-263.

Sheldon, K. M., and Elliot, A. (1999) Goal striving, need satisfaction, and longitudinal well-being: The selfconcordance model, Journal of Personality and Social Psychology,76(3), 482-497.

Slingerland, E. (2003) Effortless Action: Wu-Wei as Conceptual Metaphor and Spiritual Ideal in Early China. New York: NY: Oxford University Press.

Smith, N. R., \& Miner, J. B. (1983) Type of entrepreneur, type of firm, and managerial motivation: Implications for organizational life theory, Strategic Management Journal, 4(4), 325-340.

Stewart, A. (1989) Team Entrepreneurship. Thousand Oaks, CA: Sage Publications.

VandeWalle, D. M., Brown, S. P., Cron, W. L., and Slocum, J. W. (1999) The influence of achievement goals and self-regulation tactics on sales performance: A longitudinal test, Journal of Applied Psychology, 84(2), 249-259.

Watson, B. (Trans.) (1968) The Complete Works of Chuang Tzu. New York, NY: Columbia University Press. Wenlin Institute (2002) Wenlin Software for Learning Chinese, Version 3.0. Portland, OR: Author.

Wu, K.-M. (1990) The Butterfly as Companion: Meditations on the First Three Chapters of the Chuang Tzu. Albany, NY: State University of New York Press.

Xu, S. H. (2006) Rambling with Zhuangzi: Imagination and spontaneity for public administration and governance, Administrative Theory \& Praxis, 28(2), 275-291. 
Yearley, L. (1983) The perfected person in the radical Chuang-tzu, In V. H. Mair (Ed) Experimental Essays on Chuang-tzu, Honolulu, HI, University of Hawaii Press, 125-139.

Yearley, L. (1996) Zhuangzi’s understanding of skillfulness and the ultimate spiritual state, In P. Kjellberg and P. J. Ivanhoe (Eds) Essays on Skepticism, Relativism, and Ethics in the Zhuangzi, Albany, NY: State University of New York Press, 152-182. 


\section{Endnotes}

[1] An earlier version was presented at the Academy of Management meeting, Honolulu, HI, 2005. We are grateful for very helpful comments from sinologists Scott Cook, P. J. Ivanhoe, Victor Mair, Jordan Paper, Ted Slingerland, and Kuang-Ming $\mathrm{Wu}$, and from theologian Peter Phan.

[2] Comparing occurrences in the Zhuangzi (Lau and Chen, 2000) of "shen" with the other metaphors cited as important by Slingerland (2003, pp. 175-176), we find it occurs 112 times, compared with 57 for cong (following), 30 for sang (losing), 86 for shi (fitting), 35 for shun (flowing with), 87 for wang (forgetting), 3 for wu wei (effortless (non) action), 60 for $x u$ (emptiness, tenuous), 20 for $y i$ (fitting), 56 for $y i n$ (adapting), 54 for $y i n g$ (responding), 98 for you (playing), and 2 for $y u$ (lodge). For shen see also Puett (2003), Slingerland (2003, pp. 201-202), and Wu (1990, pp. 319-320).

[3] Chia's article is thoughtful but it offers little concerted attention to the texts themselves or current scholarship. Consequently its use of the Zhuangzi is misleading. Quoting part of the Cook Ding passage, Chia claims (2003, pp. 975-976) that it demonstrates how "the actor and the acted upon are fused in a process of mutual transformation... fused together in a spontaneous outflow of undirected action." Compare, for example, the way Cook Ding comes to a difficult spot and reorients his cutting, and his triumphant finish as he puts his knife aside with the dismembered ox at his feet (Wu, 1990, pp. 287, 295). Chia's formulation wishes away the very paradox of wu-wei itself. 
Table 1. Pagination of Relevant Passages in Major Translations and Concordances

\begin{tabular}{|c|c|c|c|c|c|}
\hline Passage & Chapter & Watson & Graham & Mair & Lau \& Chen \\
\hline Balm & 1 & $34-35$ & 47 & $7-8$ & $2-3$ \\
\hline Butcher Ding & 3 & $50-51$ & $63-64$ & $26-27$ & $7-8$ \\
\hline Wheelwright Bian & 13 & $152-153$ & $139-140$ & $128-129$ & 37 \\
\hline Cicadas (hunchback) & 19 & $199-200$ & 138 & $176-177$ & 50 \\
\hline Cicadas (hunchback) & \multicolumn{5}{|c|}{ Very similar in Liezi (列 子, Graham, 1990, 44-45) } \\
\hline Ferryman & 19 & $200-201$ & $136-137$ & 177 & 50 \\
\hline Ferryman * & \multicolumn{5}{|c|}{ Very similar in Liezi (Graham, 1990, 43-44) } \\
\hline Old swimmer & 19 & 204-205 & 136 & 182 & $51-52$ \\
\hline Old swimmer * & \multicolumn{5}{|c|}{ Very similar in Liezi (Graham, 1990, 44) } \\
\hline Carver Qing & 19 & $205-206$ & 135 & $182-183$ & 52 \\
\hline Tax collector $*$ & 20 & $212-213$ & not trans & $190-191$ & 54 \\
\hline Ubiquity (piss) & 22 & $240-241$ & 161 & 217 & $61-62$ \\
\hline Buckle maker & 22 & $244-245$ & 139 & $220-221$ & 63 \\
\hline Buckle maker * & \multicolumn{5}{|c|}{ Very similar in Huainanzi (Morgan, 124-125) } \\
\hline Archer * & \multicolumn{5}{|c|}{ Liezi (Graham, 1990, 38-39) } \\
\hline Animal tamer $*$ & \multicolumn{5}{|c|}{ Liezi (Graham, 1990, 42-43) } \\
\hline
\end{tabular}

